\title{
ВИЗИЈЕ РАЗВОЈА ЛАНАЦА СНАБДЕВАЊА СА АСПЕКТА ДИГИТАЛНЕ ТРАНСФОРМАЦИЈЕ
}

\section{VISIONS OF SUPPLY CHAINS DEVELOPMENT FROM THE ASPECT OF DIGITAL TRANSFORMATION}

\author{
Никола Јасика, Факултет техничких наука, Нови Сад
}

\section{Област - ЛОГИСТИКА}

Кратак садржај - $У$ оквиру рада анализирају се могући правции развоја ланацуа снабдевања са аспекта дигиталних трансформаџија у будућности. Први део рада односи се на теоријске поставке и истраживачке студије које се баве визијама развоја, док се у другом делу предствља могућа методологија за процену развоја логистике у Републици Србији која се базира на Делфи техниции као методи квалитативних предвиђана.

Кључне речи: ланияи снабдевања, дигитална трансформација, делфи техника, правции развоја.

\begin{abstract}
The paper analyzes possible directions of supply chain development from the aspect of digital transformations in the future. The first part of the paper refers to theoretical assumptions and research studies that deal with visions of development, while the second part presents a possible methodology for assessing the development of logistics in the Republic of Serbia based on Delphi technique as a method of qualitative predictions.
\end{abstract}

Keywords: supply chains, digital transformation, Delphi technique, directions of development.

\section{1. УВОД}

Транспортна потражња се повећава дуги низ година и на националном и на глобалном нивоу. Постојеће транспортне инфраструктуре и системи су под притиском да изнесу све веће потребе друштва. Са друге стране, број становника и њихови индивидуализовани захтеви се константно повећавају и проширују из године у годину, што ће у будућности додатно оптеретити могућности логистике и њених система. Из тог разлога, потребно је стећи увиде у могући будући развој управљања логистиком и ланцима снабдевања, како би се адекватно могло разумети и правовремено реаговати на све кључне промене које се очекују. Како је према [1], логистички систем комплексан социо-технички систем, који функционише у оквиру ширих и надређених система, онда је јасно да ће све развојне промене, које се буду дешавале у будућности, у оквиру тих ширих

\section{НАПОМЕНА:}

Овај рад проистекао је из мастер рада чији ментор је био др Маринко Масларић, ванр. проф. надређених система, имати утицај на сам логистички систем.

\section{2. ПОСТОЈЕЯИ ТРЕНДОВИ И ПРОМЕНЕ У ЛОГИСТИЦИ И УПРАВЉАЊУ ЛАНЦИМА СНАБДЕВАЊА}

Постојећи ниво техничких и технолошких могућности у логистичком сектору је без преседана. Гледајући према наредној деценији, квалитетнији подаци и повезаност пружиће основу за нове начине превоза, складиштења и дистрибуције и подржаће бољи, интегрисанији логистички систем. Главне области очекиваних будућих промена у логистици су:

- Електрификација;

- Интернет ствари;

- Вештачка интелигенција;

- Аналитика података и Big Data системи;

- Рачунарство у облаку;

- Blockchain технологија;

- Роботизација и аутоматизација;

- Еластична логистика;

- Испорука на последњем километру.

Према [2] један од главних начина на који ће се сектор транспорта и логистике мењати, јесте електрификација. Интернет ствари у логистици побољшава видљивост у сваком кораку ланца снабдевања и побољшава ефикасност управљања залихама.

Интегрисање технологије „интернет ствари“ у секторе логистике и ланаца снабдевања, побољшава и омогућава ефикасност, транспарентност, видљивост робе у реалном времену, праћење стања и управљање возним парком. Алгоритми вештачке интелигенције уз помоћ машинског учења представљају подршку компанијама при решавању колебања потражње за производима [3].

На пример, решења за предвиђање заснована на вештачкој интелигенцији омогућавају менаџерима да планирају процесе ланца снабдевања и пронађу начине за смањење оперативних трошкова. Аналитика података пружа корисне увиде за побољшање продуктивности складишта, управљање учинком и оптимално коришћење логистичких ресурса. Подаци добијени праћењем положаја и времена заједно са возним парком помажу у оптимизацији рута и планирању испоруке. Решења заснована на облаку за 
логистичке компаније омогућавају моделе плаћања по употреби који захтевају ниска капитална улагања. Ово минимизира ризик и трошкове одржавања информационо-комуникационе инфраструктуре.

Поред тога, интеграција у облак омогућава прикупљање података из система управљања за анализу укупних логистичких процеса.

Коначно, логистика у облаку нуди универзалну приступачност и није ограничена на било који физички простор. Blockchain технологија се може дефинисати као технологија дистрибуиране књиге која може да евидентира трансакције између страна на сигуран и трајан начин. Дељењем база података између више страна, у основи се уклања потреба за посредницима од којих се претходно захтевало да делују као поуздане треће стране за верификацију, евидентирање и координацију трансакција. Интегрисање роботике у логистику повећава брзину и тачност процеса ланца снабдевања и смањује људске грешке. Еластична логистика омогућава компанијама да се ефикасније носе са ланцима снабдевања током периода флуктуације потражње [3].

Последњи корак ланца снабдевања, од складишта или дистрибутивног центра до купца, често је неефикасан и такође обухвата главни део укупних трошкова премештања робе. Достава у последњем километру је најважнији део логистике јер је директно повезана са задовољством купца. Међутим, испорука на последњем километру суочава се са различитим проблемима, укључујући кашњења због загушења саобраћаја, различитости захтева купаца, административних прописа и густине испорука у једној зони [3]. Остале технологије дигитализације се односе на технологије адаптивне производње (попут ЗД штапме), blockchain технологију и др.

\section{3. ПОЈАМ ДИГИТАЛНЕ ТРАНСФОРМАЦИЈЕ}

Аутомобилски сектор је једна од најважнијих индустрија за многе индустријске земље. Са више од 20.000 делова у једном возилу, које испоручују хиљаде добављача широм света, ланац снабдевања аутомобилима и деловима, је међу најсложенијим на свету [5]. Главни трендови вођени технологијом као што су аутономна вожња, електрификација, повезаност аутомобила и мултимодалност, предвиђају да ће довести до највеће трансформације индустрије од проналаска аутомобила 1885. године.

Индустрија 4.0 представља нови ниво организације и контроле целокупног ланца стварања вредности током животног циклуса производа. Најважнија карактеристика индустрије 4.0 је дигитализација и са тиме повезана дигитална трансформација.

Дигитална трансформација у логистици може се дефинисати као трансформација ка паметној логистици помоћу технологија управљања, укључујући платформе, услуге засноване на подацима, нова управљања и организационе поставке и отворене иновације, које омогућавају стварање додатне вредности за купца [4].

Паметна логистика се дефинише као холистичко, потрошачки оријентисано планирање и контрола, високо интегрисаног и аутоматизованог, модуларног, самоконтролисаног протока информација и робе у процесу наручивања од стране купаца, као и иновације у мрежама за стварање вредности где се деле релевантне информације и подаци у реалном времену са заинтересованим странама [3].

Разлике у усвајању дигиталних технологија су видљиве када се упореде земље Европе и Азије, на пример Кина и Немачка. Мотивација за увођење нових технологија у Кини је углавном због ефикасности и смањења трошкова, док је у Немачкој због бољег планирања и доношења одлука, флексибилности и задовољства купаца. Међутим, због нижих трошкова радне снаге у Кини, повраћај улагања у технологије које побољшавају ефикасност, попут аутоматски вођених возила, нижи је него у земљама са високим трошковима.

Стога компаније, пре него што их примене у Кини, често настоје да спроводе пилот пројекте и сазревају са технологијама у развијеним земљама,. Поред високих трошкова примене нових технологија, могу се идентификовати три кључна изазова: стандардизација, сигурност података и вештине запослених.

\section{4. МАПА ПУТА КА ДИГИТАЛНОЈ ТРАНСФОРМАЦИЈИ У ЛОГИСТИЦИ}

Пошто логистика све више добија на стратешком значају за компаније и за друштво у целини, потенцијално, нова додатна вредност може се створити дигиталном трансформацијом пословних модела, испуњавањем нових очекивања купаца у погледу стицања погодности и интегрисаним маркетингом производа као системом са додатним услугама окренутим ка крајњем купцу. Логистика тако постаје фактор који омогућава нове облике дистрибуције и нове пословне моделе [4].

Део анализе и дискусије прогнозираних трендова у оквиру студије [4] представљен је у наставку. У погледу дигиталних платформи а на основу налаза студије [4] стручњаци су се у оквиру делфи радионице сложили да he ce логистички физички послови до 2025. године углавном обављати путем дигиталних платформи. Са друге стране, налази из студије [5] наводе да ће се обим, разноликост и темпо употребе података проширити у наредним деценијама, упоредо са повећањем употребе дигиталних платформи и техника за прикупљање и анализу података. Такође се у оквиру [6] наводи да модуларне платформе за логистику у облаку нуде отворен приступ путем Интернета избору флексибилних, подесивих ИТ-услуга повезаних са логистиком на захтев које се лако могу интегрисати у процесе ланца снабдевања.

У погледу руководства и организационих структура резултати из студије [4] који се тичу упитника о ројевској организацији показују да је велики број учесника или неодлучан или се у потпуности слаже да је ројевска организащија - логистичка организација будућности, док се у оквиру делфи радионице издваја просечно стручно мишљење које гласи да ће организација ројева бити успостављена као приоритетна метода рада запослених у логистици до 2028. године. 
Логистика ће вероватно проћи кроз неколико фаза на путу дигиталних трансформација. Прва фаза, омогућавања видљивости је прилично узнапредовала. Друга фаза, повећана повезаност, и даље је ометена протекционизмом података као и недостатком стандардизованих интерфејса. Међутим, компаније са најбољом праксом већ напредују на путу ка трећој фази полуаутономних процеса у логистици, укључујући примену иновативних концепата лидерства и иновација.

Потпуно аутономни процеси у ланцу снабдевања $E 2 E$ који карактеришу четврту фазу још увек су неизвесни. Долазак четврте индустријске револуције мења сва правила, а са њима и основне претпоставке и дефиниције лидерства.

\section{5. ПРЕДЛОГ ОКВИРА МЕТОДОЛОГИЈЕ ЗА ПРОЦЕНУ РАЗВОЈА ЛОГИСТИКЕ У РЕПУБЛИЦИ СРБИЈИ}

На основу обрађених истраживања, у овом делу рада je предложена одговарајућа методологија која разматра кључне кораке којима би се могли водити истраживачи, с тим да се концепт истраживања узима као оквир који се може даље уређивати, при процени будећег развоја логистике, управљања ланцима снабдевања и мапе пута ка остварењу тако пројектоване визије. У оквиру дате методологије било је потребно идентификовати и класификовати кључне факторе утицаја који могу дефинисати одређене сценарије развоја логистике и њених система. Такође, у оквиру методологије укључује се и радионица у којој се сценарији разматрају и дорађују. Учесници радионице разрађују основну логику сценарија, као и могуће путеве који воде до сваког сценарија. У наставку су приказани предложени методолошки кораци.

- $\quad$ Одабир методологије предвиђања;

- Одабир тима експерата и утицајних кључних фактора;

- Интервју са стручњацима;

- Анализа конзистентности и финализација сценарија;

- Анализа утицаја.

Пошто се одабере конкретна изворна техника, у овом случају је то делфи техника, после тога је потребно изабарти кључне особе које ће доносити експертска мишљења и предлоге. Након тога одабир широког круга фактора, што подразумева узимање у обзир свих релевантних фактора за логистику (идентификовање и класификацију фактора утицаја који одређују трендове у окружењу логистике у будућности). Даље фактори се могу унети у упитник и послати стручњацима из логистике на допуну и измену. Фактори утицаја би могли да буду: цена енергије тј. горива, ниво климатских промена, политичка стабилност и развој светске трговине, развој нових технологија и система, ниво аутоматизације, у предузећима, појединачни економски фактори и сл. Када се дефинише већа група фактора $\left(f_{l}\right)$, ради се пресек фактора у сарадњи са универзитетским стручњацима и уз помоћ анализе унакрсног утицаја свођење на мању групу кључних фактора (kfl). У наредном кораку (интервју са стручњацима) за сваки кључни фактор који има имликације на логистику и њено окружење дефинишу се потенцијални сценарији. Могуће је неколико будућих догађаја (сценарија), тако да је следећи корак спровођење интервјуа са стручњацима из различитих области како би се развиле три до четири пројекције за сваки фактор (слика 1).

После овога, потребно је извршити анализу конзистентности и смањити сложеност међу великим бројем пројекција. Дакле сваки стручњак даје за сваки фактор неколико пројекција, што резултира великим бројем могућих исхода. На основу анализе конзистентности добија се смањена група података. Резултати анализе служе за конструкцију „сирових“ сценарија $\left(s^{\prime \prime}{ }_{1}\right)$. Овакви сценарији се у наредном кораку могу дорађивати у оквиру Делфи радионице.

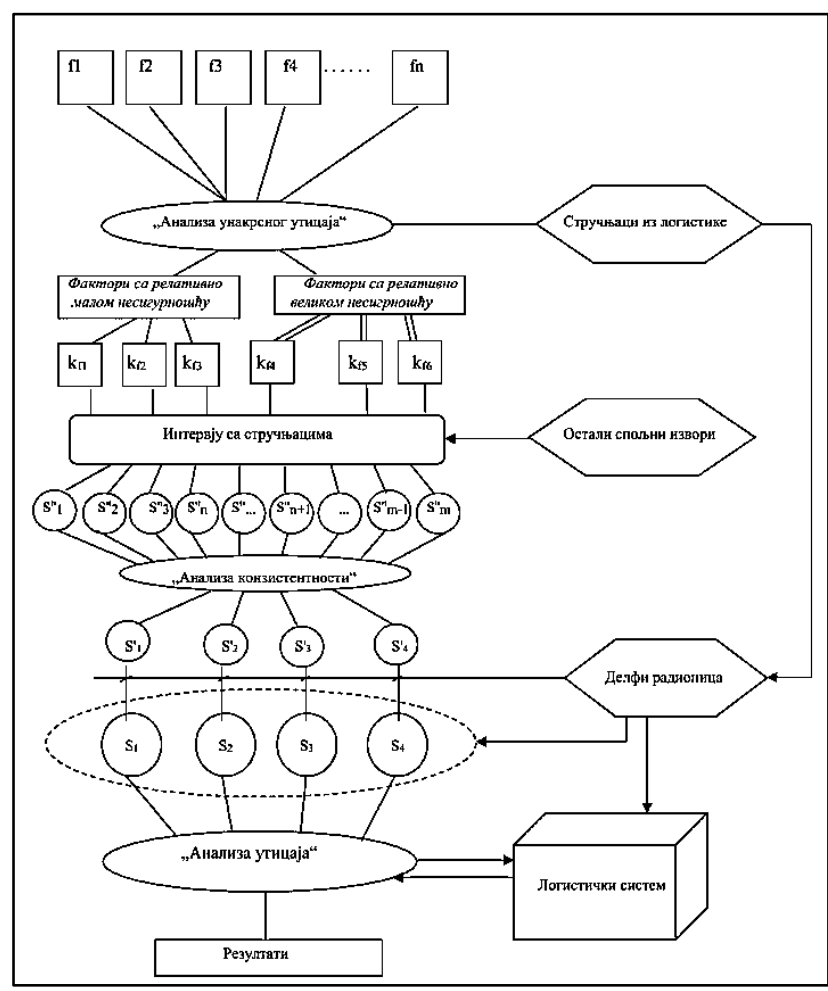

Слика 1. Шематски приказ могуће методологије по корацима (ауторово дело)

Пошто се Делфи радионица састоји из неколико методолошких корака, у наставку је приказана разрада подкорака у оквиру Делфи радионице као засебног ентитета претходне шеме. Дакле сценарији након анализе конзистентности се шаљу код лидера радионице и уносе се у упитник који се затим формира у оквиру делфи радионице. Лидер делфи радионице у сарадњи са стручњацима из логистике формира концепт упитника и разрађује сценарије у форми питања за експерте. Пре свега потребно је према [7] одабрати: стручњаке са одговарајућим доменским знањем, користити стручњаке из различитих домена, користите између 5 и 20 стручњака. Лидер делфи радионице ступа у контакт са експертима из различитих области и доставља им упитник са дефинисаним питањима. Одговори су анонимни и нико од експерата не зна шта је 
одоговорио други експерт, с тим да лидер радионице у сваком тренутку зна шта је који од експерата одговорио. Након одговора упитник се враћа код лидера (слика 2) који преуређује садржај упитника и филитра све ирелевантне одговоре који су претходно дати и фокусира се на најчешће одговореним темама и ставовима, формира извештај са одговорима свих експертских учесника, који су дати и извештај поново шаље експертима на други круг разматрања. У другом кругу сваки од експерата има могућност да делимично измени постојећи одговор (одговор који је дао у претходном кругу) или да га потпуно промени и да има увид у одговоре својих колега (слика 2)

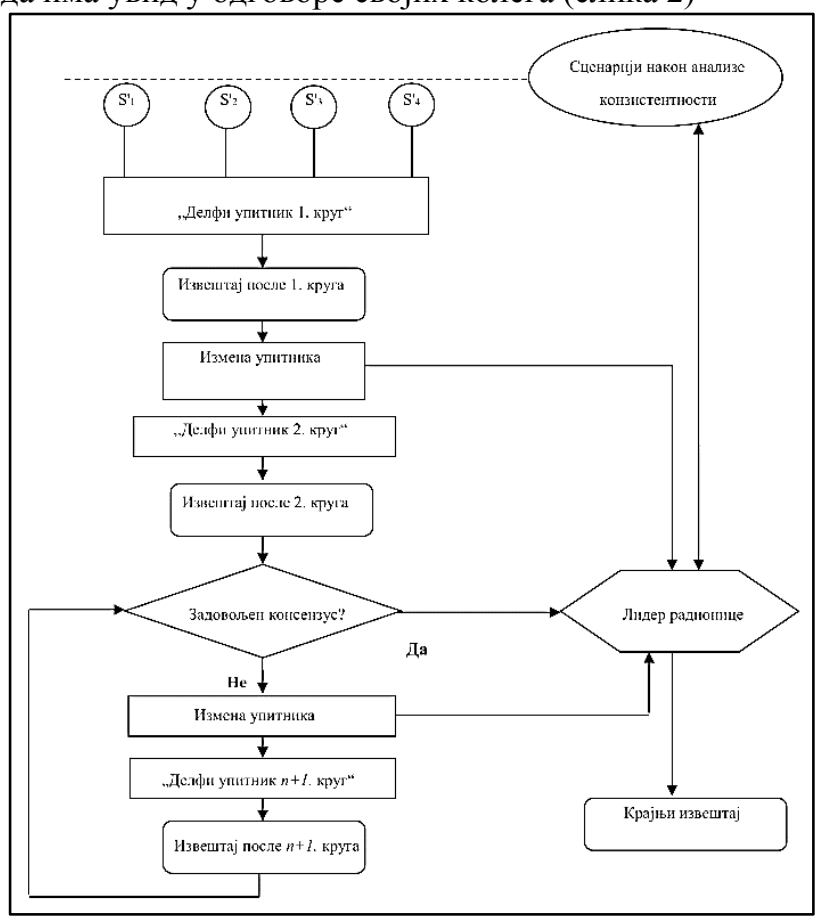

Слика 2. Оквирна шема Делфи радионице укључене у разматрану методологију (ауторово дело)

Након што су изменили своје одговаре, упитник се поново враћа код лидера који понова формира извештај са датим одговорима и анализира постојеће стање као што је приказано на слици 2. Поступак са враћањем одговора и поновним слањем експертима се понавља док год се не постигне консензус у одговорима. Такође према [7] потребно је за делфи повратне одговоре експерата, навести средњу процену панела плус образложења свих панелиста (учесника) за њихове процене. Након тога, потребно је наставити са гласањем у делфи радионици све док одговори не покажу стабилност. На крају лидер радионице има сет предвиђања који је добио на основу ставова експерата који се може даље користити.

\section{6. ЗАКЉУЧНА РАЗМАТРАҢА}

Потпуно аутономни процеси у логистичким мрежама још нису извесни, али компаније са најбољом праксом напредују, користећи се алатима као што су технологије, нова руководства и организациони принципи, као и отворени приступи иновацијама. Повезаност унутар ланаца снабдевања ће се повећати, jep ће то бити предуслов за примену концепта дигиталних транспортних платформи за коју су се стручњаци сложили да ће бити главно средство за обраду захтева за теретним превозом до 2025. Прикупљање података, анализа и употреба додате вредности довешће до (полу) аутономних процеса на тактичком нивоу, док се потпуно аутономни процеси за оперативне активности очекују до 2030. године.

Такође једна од значајних промена јесте даље брисање традиционалних секторских граница, као што се тренутно види на тржишту пружаоца логистичких услуга, које захтева трансдисциплинарне приступе иновацијама. То значи да су у кратком и средњем року једноставна мобилна решења (нпр. решења заснована на апликацијама) неопходна за интегрисање нових услуга и облика сарадње у логистичкој мрежи, и да се људи као важни елементи тих мрежа, морају прилагодити новим улогама и вештинама, што захтева иновативну обуку и управљање компетенцијама. Краткорочно и средњорочно, логистика се неће потпуно интегрисати. Повећавање видљивости биће могуће до одређене мере и откриће потенцијал, као и недостатке у логистичким мрежама који до сада нису били праћени и визуализовани.

\section{7. ЛИТЕРАТУРА}

[1] Николичић С.,Стојановић Ђ.,Масларић М.: Основи логиситке: принципи, системи и процеси, Универзитет у Новом Саду, Факултет техничких наука, 2016

[2] Vallance P.: A time of unprecedented change in the transport system, Government Office for Science, 2019.

[3] https://www.startus-insights.com/logistics-industry/

[4] Straube F.,Lisa Junge A.,Verhoeven P.,Reipert J.,Mansfeld M.: Pathway of Digital Transformation in Logistics, Technische Universität Berlin, 2019.

[5] Kerna, J.Wolff P.: The digital transformation of the automotive supply chain - an empirical analysis with evidence from Germany and China: Case study contribution to the OECD TIP Digital and Open Innovation project, 2019.

[6] Heutger, M.,Kückelhaus M.: Logistics Trend Radar Delivering insight today, creating value tomorrow version 2018/19, Bonn, 2019

[7] Grime,M.,Wright, G.:Delphi metod, 2016

\section{Кратка биографија:}

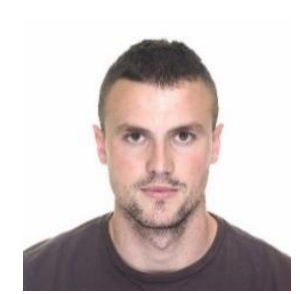

Никола Јасика, рођен у Пријепољу 1996. године. Техничку школу „Радоје Љубичић, смер Техничар друмског саобраћја завршава 2015. године и исте године уписује Факултет техничких наука у Новом Саду, на коме у септембру 2019. године стиче звање- дипломирани инжењер саобраћаја. контакт: nikola.jasika@uns.ac.rs 